\title{
The use of moisture sorption isotherms and glass transition temperature to assess the stability of powdered baby formulas
}

\author{
Ewa Ostrowska-Ligęza • Ewa Jakubczyk • \\ Agata Górska $\cdot$ Magdalena Wirkowska $\cdot$ \\ Joanna Bryś
}

Received: 31 October 2013/Accepted: 4 May 2014/Published online: 10 June 2014

(C) The Author(s) 2014. This article is published with open access at Springerlink.com

\begin{abstract}
The influence of adverse conditions of environment in the case of baby formulas, which are multiple mixtures, should be minimised. Water activity $\left(a_{\mathrm{w}}\right)$ and moisture content, correlated through sorption isotherms, and glass transition temperature have been considered relevant parameters to describe food stability. The aim of the study was to analyse water activity and glass transition temperature as the function of water content for samples of baby formulas. Three types of baby formulas (mixture, agglomerate, coated agglomerate) were determined by sorption isotherms, DSC and MDSC. DSC curves of mixture, agglomerate and coated agglomerate did not show differences in shape and course. The glass transition temperature of powders stored at different water activities was measured and it decreased with the increase in moisture content, confirming the strong plasticising effect of water on this property. Critical water activities varied from 0.14 to 0.68 and critical moisture contents varied from 0.032 to $0.062 \mathrm{~g} \mathrm{~g}^{-1}$ powder.
\end{abstract}

Keywords Baby formulas - Sorption isotherms · Glass transitions temperature $\cdot$ DSC

\section{Introduction}

Baby formulas are powders of multicomponent composition and, therefore, vary in powder structure.

E. Ostrowska-Ligęza $(\bowtie)$ · E. Jakubczyk · A. Górska ·

M. Wirkowska - J. Bryś

Faculty of Food Sciences, Warsaw University of Life Sciences,

Nowoursynowska 166, 02-776 Warsaw, Poland

e-mail: ewa_ostrowska_ligeza@sggw.pl
Amorphous and crystalline products possess different properties [1, 2]. In most milk powders, lactose is one of the main components. Lactose, protein and salts are miscible with water, while lipids have fairly little interaction with water [3, 4].

Water activity is defined as the ratio of vapour pressure of water in food to the vapour pressure of pure water at the same temperature and total pressure $[5,6]$. The description of water activity relates to equilibrium conditions. Water activity $a_{\mathrm{w}}$ is the most useful expression of water requirements for microbial growth and enzyme activity. It can be used to predict the stability of food and its shelf life [7].

Water activity depends on the composition, temperature and physical state of the compounds [8]. The knowledge of sorption data is important for many aspects related to food technology like prediction of microbiological, enzymatic and chemical stability, selection of packaging materials, designing of drying and concentration processes as well as the choice of adequate storage conditions [9]. The importance of isotherm data was presented by many authors for example: Kowalska and Lenart [10], Zhou and Labuza [11], Zhou et al. [12], Furmaniak et al. [13], Jakubczyk et al. [14], Szulc and Lenart [15]. Water sorption isotherms are important thermodynamic tools for predicting the interactions between water and food components. They describe the relationship between water activity and the equilibrium moisture content of a food product [16, 17]. Therefore, different more or less advanced sorption models have been used (with greater or smaller success) in the field of food engineering science for the description of water sorption data [13].

The glass transition temperature $\left(T_{\mathrm{g}}\right)$ is defined as the temperature at which an amorphous system changes from the glassy to the rubbery state. An important utility of $T_{\mathrm{g}}$ is made in the state diagram which, in its simplest form, 
represents the pattern of change in the state of a material as a function of increasing levels of solids [3, 8, 18]. State diagrams are graphical representations of the physical states of food constituents with respect to the temperature, moisture or solids content of foods at constant pressure for equilibrium and non-equilibrium systems $[8,19]$. The state diagram of food over the whole range of moisture content gives full information about the temperature of the different phase transitions at given moisture content and assists in predicting food stability during storage as well as selecting a suitable condition of temperature and moisture content for processing $[8,19,20]$.

DSC (differential scanning calorimetry) was found very useful in food research, for example in assess oxidation processes occurring in fats $[21,22]$, phase transitions in food powders [1, 3, 13]. Rahman [23] combined both the water activity and glass transition concepts in the state diagram. $T_{\mathrm{g}}$, which can be investigated by Modulated Differential Scanning Calorimetry (MDSC), is specific to each amorphous material and can be correlated to some caking or agglomeration of polysaccharide powders, like inulin [24] or maltodextrin [3]. It is well known that water is the major component responsible for depressing the $T_{\mathrm{g}}$ of food material. For this reason, water is considered as a strong plasticiser in a food system [25-27].

Foodstuffs with low moisture contents and $T_{\mathrm{g}}$ value above the storage temperature can be considered stable. However, a slight increase in moisture content significantly reduces $T_{\mathrm{g}}$. Therefore, moisture sorption isotherms and $T_{\mathrm{g}}$ data provide critical values for the water activity and moisture content at room temperature $[9,28,29]$. Storage of dehydrated foods at humid conditions may increase water activity $\left(a_{\mathrm{w}}\right)$ as a result of water sorption, and the glass transition of the materials may decrease to below ambient temperature. Most foods contain carbohydrates and proteins as the main non-fat solids. The glass transition behaviour of various carbohydrates is well known, but a higher $T_{\mathrm{g}}$ may be found for carbohydrate-protein mixtures than for carbohydrates alone [30]. Lactose as a milk component significantly affects the physical characteristics of dairy powders [31-33].

In the literature, glass transitions of pure components are more commonly reported than the real foods, which are more complex multi-components mixtures [34].

The aim of the study was to analyse water activity and glass transition temperature as the function of water content for samples of baby formulas. Water activity of environment, water content and glass transition temperature of powdered products are essential for predicting the storage conditions of powdered baby formulas. The obtained results will be necessary to define the shelf life of products.

\section{Materials and methods}

\section{Materials}

The powders used in this study were as follows: skim milk powder produced by District Cooperative Dairy in Koło, Poland, essential polyunsaturated fatty acids Ropufa 10 n-3; Food Powder S/SD and Ropufa 10 n-6, Food Powder distributed by DSM Nutritional Products Ltd company in Mszczonów, Poland; lactose and whey protein powder distributed by Hortimex Ltd company in Konin, Poland. The agglomerate and coated agglomerate were prepared from mixture, which was obtained from skim milk powder (9.5 mass \%), lactose (39.0 mass \%), whey protein (10.0 mass \%), essential polyunsaturated fatty acids (EPUFA) n-3 (4.5 mass \%) and n-6 (36.0 mass \%).

Mixing, agglomeration, coating and drying

Technological processes involved in the production of powder mixture were mixing, wet agglomeration, coating and drying. These processes were carried out in a fluidized bed agglomerator of the STREA 1 type produced by NiroAeromatic A.G., Bubendrof, Switzerland. $15 \%$ lactose solution as the wetting liquid (binder solution) was used in the case of wet agglomeration process in the fluidized bed as well as in coating process. A sample of food powder weighing $300 \mathrm{~g}$ was placed in the product container, and fluidized by means of an upward flowing air stream. The temperature of the inlet fluidizing air entering the bed was set at $50{ }^{\circ} \mathrm{C}$. During agglomeration and coating, it was necessary to increase fluidizing air flow regularly in order to maintain correct fluidization of enlarged agglomerates. When the binder solution had been used up, the product was dried for $15 \mathrm{~min}$ at $50{ }^{\circ} \mathrm{C}[10,35,36]$.

\section{Differential scanning calorimetry}

Phase and glass transition temperatures were measured and recorded on differential scanning calorimeter (DSC, TA Instruments Q 200, New Castle, USA). Before the calorimetric experiments, all samples were dried for $24 \mathrm{~h}$ in a vacuum, under pressure of $13 \mathrm{kPa}$ and at a temperature of $50{ }^{\circ} \mathrm{C}$. The powders were stored in desiccator with $\mathrm{CaCl}_{2}$ about water activity close to 0 at $22{ }^{\circ} \mathrm{C}$. The first DSC experiment consisted of appointment of temperature of phase transitions. The powders $(10-15 \mathrm{mg})$ were non-hermetically sealed in aluminium pans (volume $30 \mathrm{~L}$ ). The samples were heated from $-60{ }^{\circ} \mathrm{C}$ up to $300{ }^{\circ} \mathrm{C}$ with the heating rate of $5^{\circ} \mathrm{C} \mathrm{min}^{-1}$. The DSC technique was used to obtain heat flow $\left(\mathrm{W} \mathrm{g}^{-1}\right)$ versus temperature curves [3]. The cell was purged with dry nitrogen at $50 \mathrm{~mL}$ per minute and calibrated for baseline on an empty oven and for 
temperature using standard pure indium. Specific heat capacity was calibrated using a sapphire standard. An empty pan was used as the reference.

The samples were tested using the same method after storage. The DSC experiments were done without vacuum drying of samples. The powder samples were measured at water activity about $0.32-0.36$. Water content of mixture, agglomerate and coated agglomerate were, respectively,

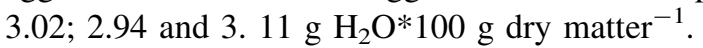

\section{Sorption isotherms}

Water vapour adsorption isotherms were determined using the static-gravimetric method. The products were stored at a stable relative humidity, which ranged from 0.0 to 0.9 , for 3 months, at temperature $25^{\circ} \mathrm{C}$ [37]. The products to be analysed were placed in desiccators. Saturated salt solutions were used as hygroscopic factors. The salts were $\mathrm{CaCl}_{2}, \mathrm{LiCl}, \mathrm{CH}_{3} \mathrm{COOK}, \mathrm{MgCl}_{2}, \mathrm{~K}_{2} \mathrm{CO}_{3}, \mathrm{Mg}\left(\mathrm{NO}_{3}\right)_{2}$, $\mathrm{NaNO}_{2}, \mathrm{NaCl},\left(\mathrm{NH}_{4}\right)_{2} \mathrm{SO}_{4}$ and $\mathrm{BaCl}_{2}$ with water activities of $0,0.113,0.225,0.329,0.438,0.529,0.648,0.753,0.810$ and 0.903 , respectively. Before measurement, the moisture content was determined by drying the powder samples at $50{ }^{\circ} \mathrm{C}$ for $24 \mathrm{~h}$ [14]. Water content was determined according to PN-EN ISO 5537:2006 [38]. The water activity was determined using the HygroLab C1 (Rotronic Instruments, UK).

The Peleg model (1) available in the literature [39] was evaluated by determining the best fit to the experimental data presented in Fig. 3.

$m=A \cdot a_{\mathrm{w}}^{\mathrm{B}}+C \cdot a_{\mathrm{w}}^{\mathrm{D}}$

The $m$ and $a_{\mathrm{w}}$ are equilibrium moisture content and water activity, respectively. The other symbols are the model constants.

The fitting of Peleg model was checked by coefficient of determination $\left(R^{2}\right)$.

\section{Modulated differential scanning calorimetry}

MDSC (modulated differential scanning calorimetry) was used to determine the glass transition temperature of powders. The samples were scanned from -60 to $300{ }^{\circ} \mathrm{C}$ at a constant heating rate of $2{ }^{\circ} \mathrm{C} \mathrm{min}^{-1}$ with an amplitude of $\pm 1{ }^{\circ} \mathrm{C}$ and $60 \mathrm{~s}$ period of modulation. Curves were analysed with respect to the total, reversible and nonreversible heat flow [26]. Glass transition was reported with parameters indicating its onset, midpoint and endpoint of a vertical shift in the reversing transition curve. The powders at water activity close to 0 were non-hermetically sealed in aluminium pans. The powders at higher water activity were sealed in hermetically aluminium pans. TA Instruments Universal analysis software was used to analyse the glass transition temperature. All of the measurements were performed in triplicate [14, 40, 41].

The glass transition temperature of foods was modelled by Gordon-Taylor equation (2) [42]:

$T_{\mathrm{gm}}=\frac{X_{\mathrm{s}}\left(T_{\mathrm{gs}}\right)+k X_{\mathrm{s}}\left(T_{\mathrm{gw}}\right)}{X_{\mathrm{s}}+k X_{\mathrm{s}}}$,

where $X_{\mathrm{s}}$ and $X_{\mathrm{w}}$ are the mass fractions of solid and water (w.b.), respectively; $T_{\mathrm{gm}}, T_{\mathrm{gs}}$ and $T_{\mathrm{gw}}$ are the glass transition temperatures of the sample, solids and water, respectively. $T_{\mathrm{gw}}=-135^{\circ} \mathrm{C} ; \mathrm{k}$ is the Gordon-Taylor parameter $[8,42]$.

\section{Statistical analysis}

Each analysis was carried out in triplicate. The data were reported as the mean \pm SD. Two-way ANOVA was performed using Statgraphics Plus for Windows program, version 4.1 (Statistical Graphics Corporation, Warrenton, VA, USA). Differences were considered to be significant at a $P$ value of 0.05 , according to Tukey's Multiple Range Test.

\section{Results and discussion}

The subjects of research were three models of baby formulas. The first baby formula was the mixture of pure ingredients, the second one was agglomerated by $15 \%$ wetting liquid and the third one was coated agglomerate. Crystal lactose was the main ingredient in all baby formulas. The DSC curves are presented in Fig. 1. The DSC curves of mixture, agglomerate and coated agglomerate were characterized by two endothermic, distinct peaks. The maximum temperature of first endothermic peak was observed at $143{ }^{\circ} \mathrm{C}$ for all powders. The second distinct, endothermic peak for mixture, agglomerate and coated agglomerate was observed at the temperature of $208{ }^{\circ} \mathrm{C}$. The third endothermic peak on DSC curve of mixture was determined at the temperature of $216^{\circ} \mathrm{C}$. DSC diagrams of agglomerate and coated agglomerate were characterized by the same three peaks, for which the intensity was lower than in the case of mixture peak. The exothermic peaks observed above temperature of $250{ }^{\circ} \mathrm{C}$ according to the literature [43] were a result of sample decomposition. The shape and course of DSC curves of agglomerate and coated agglomerate were very similar to DSC diagram of mixture baby formula (Fig. 1). The process (agglomeration or coating) has no influence on thermal properties of studied powders. Gombas et al. [44] and Szepes et al. [45] studied temperatures of phase transitions of both amorphous and crystalline lactose and observed the endothermic peaks on DSC curves at $144{ }^{\circ} \mathrm{C}$ (water evaporation) and $213{ }^{\circ} \mathrm{C}$ 


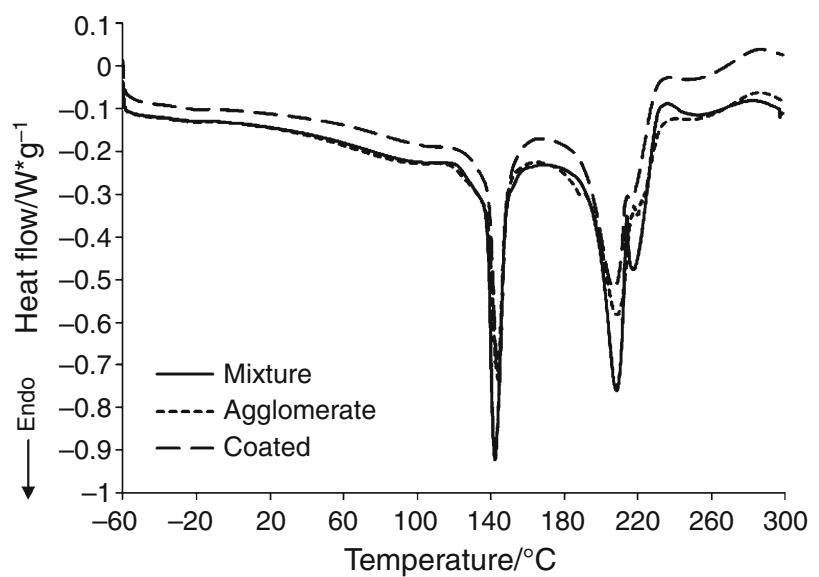

Fig. 1 DSC curves of mixture, agglomerate and coated agglomerate baby formulas

(genuine melting of $\alpha$-lactose) for crystalline lactose, respectively. In DSC diagram of $100 \%$ crystalline $\alpha$-lactose an endothermic peak at $144{ }^{\circ} \mathrm{C}$ is observed, which represents the loss of crystalline water [44, 45]. Melting temperatures of $100 \%$ crystalline $\alpha$ - and $\beta$-lactose were observed by Gombas et al. [44] at $213{ }^{\circ} \mathrm{C}$ and $224{ }^{\circ} \mathrm{C}$, respectively. However, according to the literature data [23], the temperature of melting point of pure lactose is higher and depends on the state of the sugar. The temperature of melting lactose (especially $\beta$-lactose) measured in our experiments differed from that obtained by Gombas [44] and Szepes [45], mainly due to the effect of different ingredients of baby formulas. Chiou et al. [1] determined the influence of spray drying parameters on thermal properties of lactose. The volume of exothermic peak is dependent on amorphous lactose content as shown by Chiou et al. [1]. Based on the shape and course of DSC diagrams of studied baby formulas [3, 46] differences in composition of baby formulas can be observed.

Powders (mixture, agglomerate and coated agglomerate) were stored in plastic bags for 6 months at $20-22{ }^{\circ} \mathrm{C}$, and air relative humidity was $42-45 \%$. Efforts were made during storage to maintain room (normal) conditions of storage.

The effect of storage of the mixture, agglomerate and the coated agglomerate is shown in Fig. 2. The shape and course of all baby formula DSC curves before and after storage were very similar. Besides the three endothermic peaks near 140,210 and $216{ }^{\circ} \mathrm{C}$, an additional mild and broad endothermic peak was detected between 35 and $120{ }^{\circ} \mathrm{C}$. This transition was the result of an increase of water content in the samples. The peaks observed between 35 and $120^{\circ} \mathrm{C}$ were corresponded to the evaporation of water. The process of agglomeration and coating has the same influence on water sorption by powders during

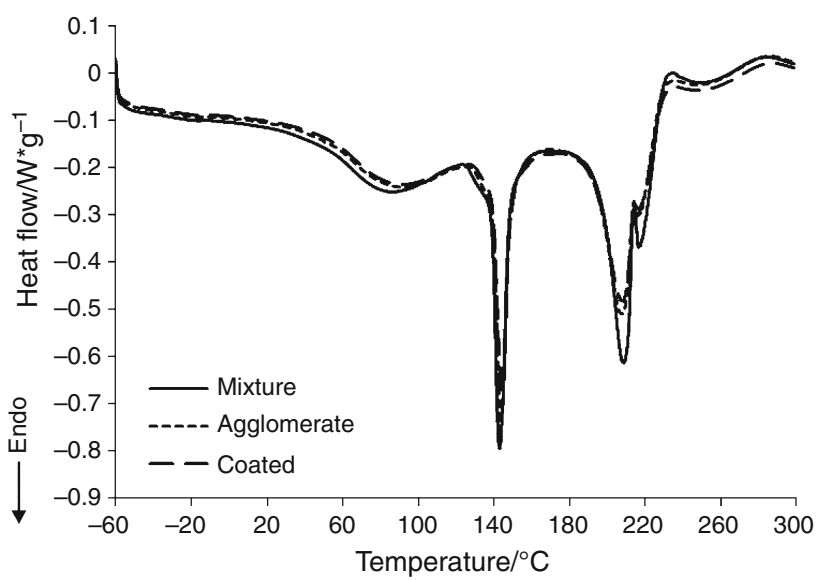

Fig. 2 DSC curves of mixture, agglomerate and coated agglomerate baby formulas after six months of storage

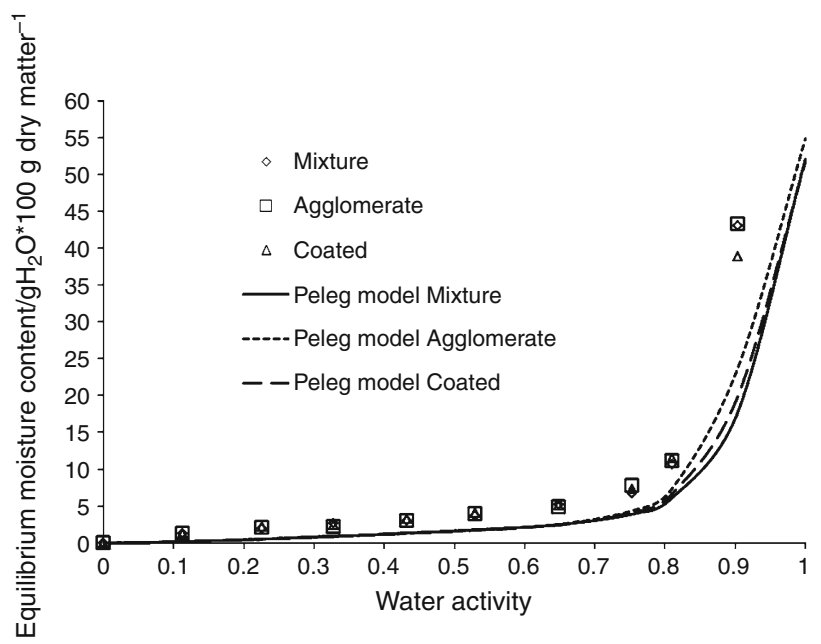

Fig. 3 Moisture sorption isotherms of powdered baby formulas

storage. The moisture content of powders has increased during storage. Thomas et al. [47] studied the effect of storage conditions $\left(20^{\circ} \mathrm{C}\right.$, range of water activity $0.11-0.95$, time of storage -3 months) on stability of the mixtures of lactose and whey protein and showed that the high content of lactose improved the stability of the mixtures.

The moisture sorption isotherm of baby formula powders measured at $25{ }^{\circ} \mathrm{C}$ is shown in Fig. 3. The water vapour sorption isotherms of the mixture, agglomerate and coated agglomerate showed a characteristic sigmoid shape, the most common in foods [10, 48, 49]. This sigmoid shape indicated a II type according to BET classification [50]. The wet agglomeration of food powders analyzed in this study, and wetting liquid used in the process (agglomeration or coating) had no significant influence on the shape of 
Table 1 Peleg model fitting for experimental data

\begin{tabular}{llllrr}
\hline Material & $A$ & $B$ & $C$ & $D$ & $R^{2}$ \\
\hline Mixture & $0.5980 \pm 0.0223$ & $14.3376 \pm 0.0147$ & $0.0431 \pm 0.0049$ & $1.3692 \pm 0.0642$ & 0.9997 \\
Agglomerate & $0.8555 \pm 0.0071$ & $15.2461 \pm 0.0057$ & $0.0484 \pm 0.0114$ & $1.2983 \pm 0.0127$ & 0.9998 \\
Coated agglomerate & $0.6648 \pm 0.0187$ & $13.9158 \pm 0.0321$ & $0.0421 \pm 0.0165$ & $1.3833 \pm 0.0282$ & 0.9997 \\
\hline
\end{tabular}

the water vapour sorption isotherms. The sigmoid shape sorption isotherms are usually observed for dairy powders [51-53]. Szulc and Lenart [15] carried out a few model of agglomerated baby formula sorption isotherms. The wetting liquid (water, $2 \%$ lecithin solution, 50\% sugar solution), which was used in agglomeration or coating process had no influence on the agglomerated baby formula powders ability for water vapour sorption. The analysis of the course of water vapour sorption isotherms had allowed to determine the water sorption limit. Above water activity 0.75 , a significant increase in water adsorption can be observed. The rapid increase of water content was observed in samples beyond this level of water activity (Fig. 2). Shape and course of water vapour sorption isotherms are more dependent on the composition of powders than on the agglomeration or coating processes (with different kinds of wetting liquid).

The water vapour sorption isotherms can be described by many models. The Peleg model is one of the simplest four-parameter model consisting with the double power expression (1) that can describe sigmoid shape of sorption curve. The construction of formula with two elements $A \cdot a_{\mathrm{w}}^{\mathrm{B}}$ and $C \cdot a_{\mathrm{w}}^{\mathrm{D}}$ enables to obtain the sigmoid shape of the sorption isotherm. The Peleg model [39] was the only available in the literature that fits to the experimental data (Fig. 3 and Table 1). The Peleg equation is suitable to describe II and III type of sorption isotherms model.

The three-parameters model developed by Anderson [54], De Boer [55] and Guggenheim [56] known as the GAB model describes sorption isotherm. The model is based on the theory of gas adsorption to surfaces. Modelling of water sorption isotherms of foods has been carried out using the GAB equation by many authors, but the model has some limitations. An attempt to apply the GAB model was undertaken, but the parameters of the GAB equation for baby formulas (data are not presented) did not satisfy the conditions stipulated by Lewicki [57] so as to be eligible for experimental data description. Results presented in Table 1 indicated that the Peleg's model best describes the experimental adsorption and data for mixture, agglomerated and coated mixture with using $15 \%$ lactose solution on the process. Peleg developed a semi-empirical four-parameter model to describe sigmoid shape of moisture sorption isotherms (Table 1). In product which contained crystalline sugars (for example baby formulas) with increasing water content, dissolution of sugars occurred. It might lead to the creation of the solution with concentration close to saturation. A level of adsorbed water significantly increased. The system has aimed to ensure thermodynamic balance with an environment [58-60]. Peleg equation turned out to be well fitted for equilibrium moisture sorption data for different products at water activity up to about $0.85-0.95$ [14, 61]. Spada et al. [62] carried out adsorption isotherms for microcapsules with hydrolyzed pinhao starch. They have determined isotherms between 10 and $30{ }^{\circ} \mathrm{C}$ (the temperature range studied) and a water activity range from 0.11 to 0.98 , the Peleg model fitted the experimental data well. The Peleg models were used to perform variation of water activity with equilibrium moisture content of the mixture, agglomerate and coated agglomerate baby formulas.

The relationships between water activity and glass transition temperature $\left(T_{\mathrm{gm}}\right)$ as a functions of equilibrium moisture content are shown in Figs. 4, 5 and 6 for the mixture, agglomerate and coated agglomerate, respectively. The glass transition temperature obtained for experimental data of baby formulas are shown in Table 2. Gordon-Taylor model fitting for experimental data of mixture, agglomerate and coated agglomerate is shown in Table 3. The values of glass transition decreased with water contents increasing as shown in curves of variations of glass transition temperature, water activity with equilibrium moisture content of all baby formula (Figs. 4, 5, 6). According to glass transition conception for temperature $25{ }^{\circ} \mathrm{C}$ (temperature of determination sorption isotherms), the value of critical water activity was 0.14 and value of equilibrium moisture content $0.062 \mathrm{~g}$ water $\cdot \mathrm{g} \mathrm{powder}^{-1}$ for mixture. The stability of mixtured baby formula was the best in, or below, that value of water activity and water content at storage temperature $\left(25^{\circ} \mathrm{C}\right)$. The value of critical water activity and equilibrium moisture content for agglomerate was different, 0.68 and $0.038 \mathrm{~g}$ water $\cdot \mathrm{g}$ powder $^{-1}$, respectively (Fig. 5). The best value of critical water activity during storage proved to be much higher than for mixture. The value of water activity was 0.29 and the value of equilibrium moisture content $0.032 \mathrm{~g}$ water $\cdot \mathrm{g}$ powder $^{-1}$ for coated agglomerate according to glass transition conception (Fig. 6). Peleg model was the best fitted 


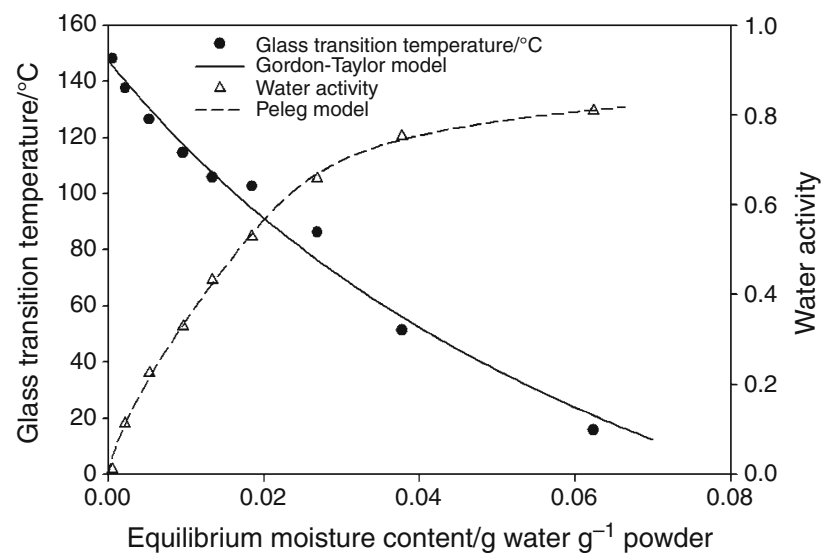

Fig. 4 Variation of glass transition temperature, water activity with equilibrium moisture content of mixture baby formula

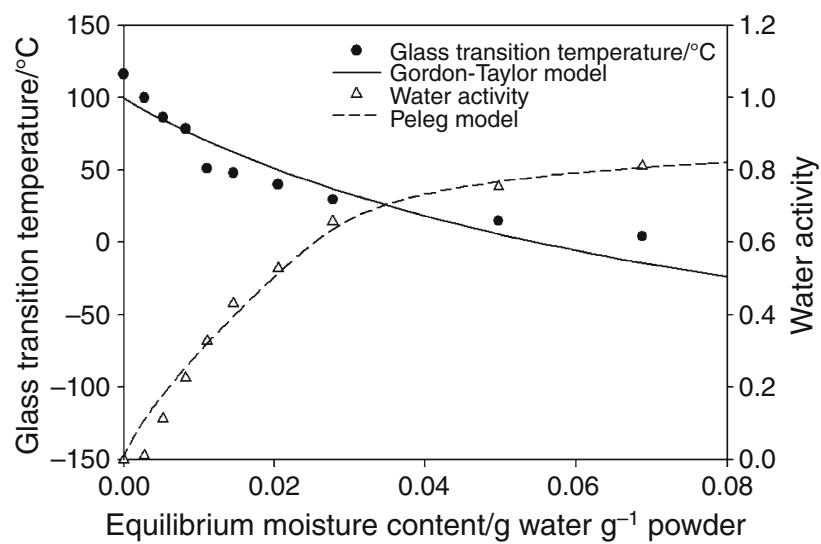

Fig. 5 Variation of glass transition temperature, water activity with equilibrium moisture content of agglomerate baby formula

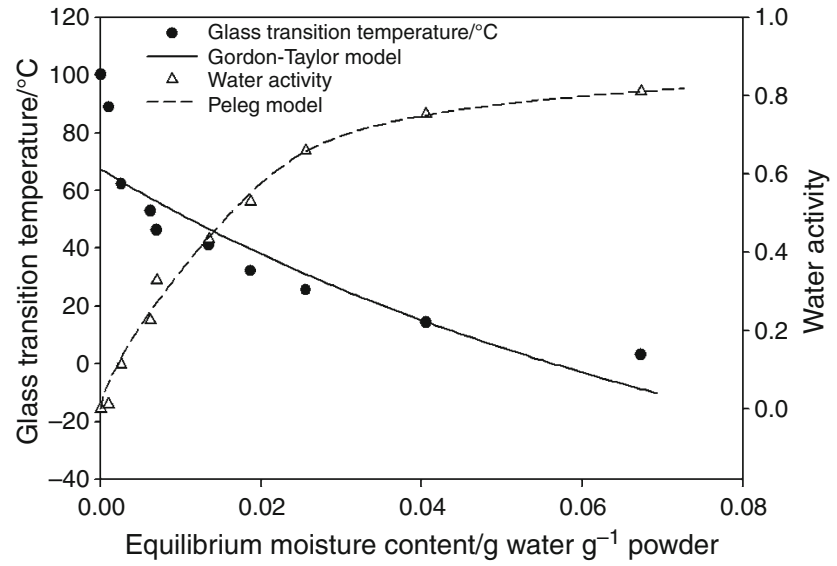

Fig. 6 Variation of glass transition temperature, water activity with equilibrium moisture content of coated agglomerate baby formula

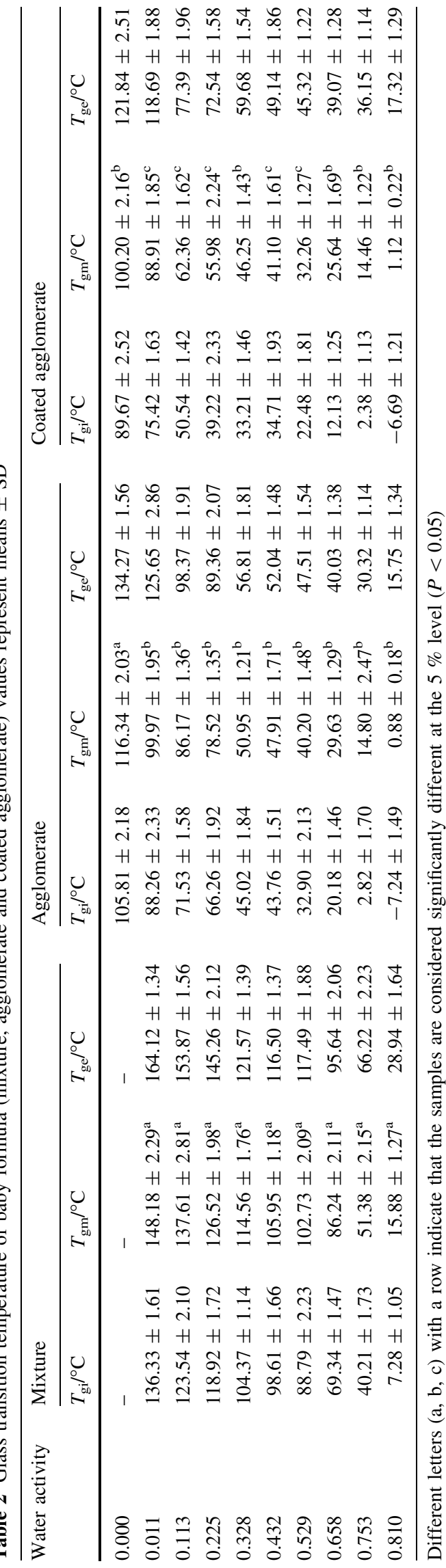


Table 3 Gordon-Taylor model fitting for experimental data

\begin{tabular}{lrrl}
\hline Material & \multicolumn{1}{c}{$T_{\mathrm{gs}}{ }^{\circ} \mathrm{C}$} & \multicolumn{1}{l}{$k$} \\
\hline Mixture & $147.32 \pm 0.05$ & $12.18 \pm 0.74$ & 0.9827 \\
Agglomerate & $99.42 \pm 0.67$ & $12.69 \pm 0.86$ & 0.8780 \\
Coated agglomerate & $67.38 \pm 0.28$ & $8.34 \pm 0.39$ & 0.8300 \\
\hline
\end{tabular}

to the experimental sorption isotherms. There is no monolayer in this model. The water activity conception coincided with glass transition conception. The main ingredient of experimental baby formula was lactose. The presence of sugar increased water activity of agglomerate and coated agglomerate during storage. Roos [26] carried out state diagrams of maltodextrin with different $\mathrm{DE}(5,10$, 20 and 36). The critical water activity of powders ranged from 0.45 to 0.70 at storage temperature $25^{\circ} \mathrm{C}$. The critical water content ( $\mathrm{g}$ water $\cdot 100 \mathrm{~g}$ dry mater ${ }^{-1}$ ) of maltodextrin samples reached the values of about 10. Tonon et al. [17] obtained high values of critical water activity and moisture content (g water $\cdot 100 \mathrm{~g}$ dry mater ${ }^{-1}$ ) at $25{ }^{\circ} \mathrm{C}$ for maltodextrin (DE 10 and 20) (0.574 and 0.086; 0.535 and 0.083, respectively), for gum arabic (0.571 and 0.100 , respectively) and tapioca starch ( 0.554 and 0.061 , respectively). The mixtures of lactose and salts $\left(\mathrm{NaCl}, \mathrm{CaCl}_{2}, \mathrm{KCl}\right.$ and $\mathrm{MgCl}_{2}$ ) were used to obtain state diagrams by Omar and Roos [4]. They determined values of critical water activity and moisture content ( $\mathrm{g}$ water $\cdot 100 \mathrm{~g}$ dry mater $^{-1}$ ); for all mixtures the values ranged from 0.4 to 10 . The ingredients of experimental baby formulas, except crystalline lactose, were skim milk powder, powdered fatty acids and whey protein. The interactions between ingredients were present. These experiments are the beginning and the results obtained are preliminary and require further research. Data on water sorption and $T_{\mathrm{g}}$ of baby formulas are helpful for evaluation of proper dehydration, processing and storage conditions for dairy foods.

\section{Conclusions}

DSC curves of mixture, agglomerate and coated agglomerate did not show differences in shape and course. The shape of DSC curves of baby formulas has changed after storage, because of increased water content. Sorption isotherms of baby formula belonged to II type according to BET classification. There is no influence of agglomeration or coating process on shape and course of baby formulas sorption isotherms. The glass transition temperature of powders stored at different water activities was measured and it decreased with the increase in moisture content, confirming the strong plasticizing effect of water on this property. The obtained results provide an opportunity to predict the critical water activities of environment and critical moisture contents of studied powders. Above these values, agglomerate baby formula can become collapsed and sticky. However, for a complete study of powder stability, it is necessary to continue experiments.

Acknowledgements This work was supported by the Ministry of Science and Higher Education grant no. NN312 366637. The results of this research were presented at the CEEC-TAC2 Conference.

Open Access This article is distributed under the terms of the Creative Commons Attribution License which permits any use, distribution, and reproduction in any medium, provided the original author(s) and the source are credited.

\section{References}

1. Chiou D, Langrish T, Braham R. The effect of temperature on the crystallinity of lactose powders produced by spray drying. J Food Eng. 2008;86:288-93.

2. Ostrowska-Ligęza E, Górska A, Wirkowska M, Koczoń P. An assessment of various powdered baby formulas by conventional methods (DSC) or FT-IR spectroscopy. J Therm Anal Calorim. 2012;110:465-77.

3. Roos Y, Karel M. Plasticizing effect of water on thermal behaviour and crystallization of amorphous food models. J Food Sci. 1991;56(1):38-43.

4. Omar E, Roos Y. Glass transition and crystallization behaviour of freeze-dried lactose-salt mixtures. LWT. 2007;40:536-43.

5. Scott W. Water relations of Staphylococcus aureus at $30{ }^{\circ} \mathrm{C}$. Aust J Biol Sci. 1953;6:549-64.

6. Scott W. Water relations of food spoilage microorganisms. Adv Food Res. 1957;7:83-124.

7. Troller J, Christian J. Water activity in food. New York: Academic Press; 1978. p. 7.

8. Shi Q, Wang X, Zhao Y, Fang Z. Glass transition and state diagram for freeze-dried Agaricus bisporus. J Food Eng. 2012;111:667-74.

9. Mrad N, Bonazzi C, Boudhrioua N, Kechaou N, Courtois F. Influence of sugar composition on water sorption isotherms and on glass transition in apricots. J Food Eng. 2012;111:403-11.

10. Kowalska J, Lenart A. The influence of ingredients distribution on properties of agglomerated cocoa products. J Food Eng. 2005;68:155-61.

11. Zhou P, Labuza T. Effect of water content on glass transition and protein aggregation of whey protein powders during short-term storage. Food Biophys. 2007;2:108-16.

12. Zhou P, Liu X, Labuza T. Moisture-inducted aggregation of whey proteins in a protein/buffer model system. J Agr Food Chem. 2008;56:2048-54.

13. Furmaniak S, Terzyk A, Gołembiewski R, Gauden P, Czepirski L. Searching the most optimal model of water sorption on foodstuffs in the whole range of relative humidity. Food Res Int. 2009;42:1203-14.

14. Jakubczyk E, Ostrowska-Ligęza E, Gondek E. Moisture sorption characteristics and glass transition temperature of apple puree powder. Int J Food Sci Tech. 2010;45:2515-23.

15. Szulc K, Lenart A. Water vapour adsorption properties of agglomerated baby food powders. J Food Eng. 2012;109:135-41.

16. Lomauro C, Bakshi A, Labuza T. Evaluation of food moisture isotherm equations. 1: fruit, vegetable and meat products. LWT. 1985;18(2):111-7. 
17. Tonon R, Baroni A, Brabet C, Gibert O, Pallet D, Hubinger M. Water sorption and glass transition temperature of spray dried açai (Euterpe oleracea Mart.) juice. J Food Eng. 2009;94:215-21.

18. Sablani S, Kasapis S, Rahman M, Al-Jabri A, Al-Habsi N. Sorption isotherms and the state diagram for evaluating stability criteria of abalone. Food Res Int. 2004;37:915-24.

19. Sablani S, Syamaladvi R, Swanson B. A review of methods, data, and application of state diagrams of food systems. Food Eng Reviews. 2010;2:168-203.

20. Fabra M, Talens P, Moraga G, Martínez-Navarrete N. Sorption isotherm and state diagram of grapefruit as a tool to improve product processing and stability. J Food Eng. 2009;93:52-8.

21. Bryś J, Wirkowska M, Górska A, Ostrowska-Ligęza E, Bryś A, Koczoń P. The use of DSC and FT-IR spectroscopy for evaluation of oxidative stability of interesterified fats. J Therm Anal Calorim. 2013;112:481-7.

22. Wirkowska M, Górska A, Bryś J, Ostrowska-Ligęza E, Koczoń P. Oxidative stability and triacylglycerols structure of lipid fraction from cookies for infants. Int J Food Sci Nutr. 2012;63(3):296-302.

23. Rahman M. Food stability determination by macro-micro region concept in the state diagram and by defining a critical temperature. J Food Eng. 2010;99:402-16.

24. Schaller-Povolny L, Smith D, Labuza T. Effect of water content and molecular weight on the moisture isotherms and glass transition properties of inulin. Int J Food Prop. 2000;3:173-92.

25. Kalichevsky M, Blanshard J, Tokarczuk P. Effect of water content and sugars on the glass transition of casein and sodium caseinate. Int J Food Sci Tech. 1993;28:139-51.

26. Rahman M, Al-Marhubi I, Al-Mahrouqi A. Measurement of glass transition temperature by mechanical (DMTA), thermal (DSC and MDSC), water diffusion and density methods: a comparison study. Chem Phys Lett. 2007;440:372-7.

27. Ronkart S, Blecker C, Fougnies C, Van Herck J, Wouters J, Paquot M. Determination of physical changes of inulin related to sorption isotherms: an X-ray diffraction, modulated differential scanning calorimetry and environmental scanning electron microscopy study. Carbohyd Polym. 2006;63:210-7.

28. Khalloufi S, El-Maslouhi Y, Ratti C. Mathematical model for prediction of glass transition temperature of fruit powders. J Food Sci. 2000;65:842-5.

29. Roos Y. Characterization of food polymers using state diagrams. J Food Eng. 1995;24:339-60.

30. Haque M, Roos Y. Water sorption and plasticization behaviour of spray-dried lactose/protein mixtures. J Food Sci. 2004;69(8):384-91.

31. Jouppila K, Roos Y. Water sorption and time dependent phenomena of milk powders. J Dairy Sci. 1994;77:1798-808.

32. Silalai N, Roos Y. Roles of water and solids composition in the control of glass transition and stickiness of milk powders. J Food Sci. 2010;75(5):285-96.

33. Zhou Y, Roos Y. Characterization of carbohydrate-protein matrices for nutrient delivery. J Food Sci. 2011;76(4):368-76.

34. Guizani N, Al-Saidi G, Rahman M, Bornaz S, Al-Alawi A. State diagram of dates: glass transition, freezing curve and maximalfreeze-concentration condition. J Food Eng. 2010;99:92-7.

35. Jinapong N, Suphantharika M, Jamnong P. Production of instant soymilk powders by ultrafiltration, spray drying and fluidized bed agglomeration. J Food Eng. 2008;84:194-205.

36. Wirkowska M, Ostrowska-Ligęza E, Górska A, Koczoń P. Thermal properties of fats extracted from powdered baby formulas. J Therm Anal Calorim. 2012;110:137-43.

37. Spiess W, Wolf W. Critical evaluation of methods to determine moisture sorption isotherms. In: Louis B, editor. Water activity: theory and applications to food. New York: CRC Press; 1987. p. 215-24.

38. PN-EN ISO 5537:2006. Milk powder-determination of water content.
39. Peleg M. Assessment of a semi-empirical four parameter general model for sigmoid moisture sorption isotherms. J Food Process Eng. 1993;16:21-37.

40. Górska A, Ostrowska-Ligęza E, Szulc K, Wirkowska M. A differential scanning calorimetric study of $\beta$-lactoglobulin and vitamin $\mathrm{D}_{3}$ complexes. J Therm Anal Calorim. 2012;110:473-7.

41. Górska A, Szulc K, Ostrowska-Ligęza E, Wirkowska M, Bryś J. The influence of trehalose-maltodextrin and lactose-maltodextrin matrices on thermal and sorption properties of spray-dried $\beta$ lactoglobulin-vitamin D3 complexes. J Therm Anal Calorim. 2013;112:429-36.

42. Gordon M, Taylor J. Ideal copolymers and the second-order transitions of synthetic rubbers. 1. Non-crystalline copolymers. J Appl Chem. 1952; 2: 493-500.

43. Fierz H. Use of calorimetry to evaluate safety of processing. In: Kaletunc G, editor. Calorimetry in food processing. New York: IFT Press, Wiley-Blackwell; 2009. p. 351-67.

44. Gombas A, Szabo-Revesz P, Kata M, Regdon G Jr, Erös I. Quantitative determination of cristallinity of $\alpha$-lactose monohydrate by DSC. J Therm Anal Calorim. 2002;68:503-10.

45. Szepes A, Fiebig A, Ulrich J, Szabo-Revesz P. Structural study of $\alpha$-lactose monohydrate subjected to microwave irradiation. J Therm Anal Calorim. 2007;89(3):560-75.

46. Ostrowska-Ligęza E, Szulc K, Wirkowska M, Górska A, Lenart A. Influence of agglomeration and coating on oxidation stability of essential unsaturated fatty acids of powdered baby formulas. Acta Agrophys. 2012;19(1):77-88 (in Polish).

47. Thomas M, Scher J, Desobry S. Lactose/ $\beta$-Lactoglobulin interaction during storage of model whey powders. J Dairy Sci. 2004;87:1158-66.

48. Mathlouthi M, Roge B. Water vapour sorption isotherms and the caking of food powders. Food Chem. 2003;82:61-71.

49. Medeiros M, Ayrosa A, Nogueira de Moraes P. Sorption isotherms of cocoa and cupuassu products. J Food Eng. 2006;73:402-6.

50. Brunauer S, Deming L, Deming W, Teller E. On a theory of the van der Waals adsorption of gases. J Am Chem Soc. 1940;62: $1723-32$.

51. Foster K, Bronlund J, Paterson A. The prediction of moisture sorption isotherms for dairy powders. Int Dairy J. 2005;15:411-8.

52. Shrestha A, Howes T, Adhikari B, Wood B, Bhandari B. Water sorption and glass transition properties of spray-dried lactose hydrolysed skim milk powder. LWT. 2007;40:1593-600.

53. Anderson R. Modification of the Brunauer, Emmett and Teller equations. J Am Chem Soc. 1946;68:686-91.

54. De Boer J. The dynamic character of adsorption. Oxford: Clarendon Press; 1953.

55. Guggenheim E. Application of statistical mechanics. Oxford: Clarendon Press; 1966.

56. Sawhney I, Sarkar B, Patil G. Moisture sorption characteristics of dried acid casein from buffalo skim milk. LWT. 2011;44:502-10.

57. Lewicki P. The applicability of the GAB model to food water sorption isotherms. Int J Food Sci Tech. 1997;32:553-5.

58. Lewicki P. Properties of water in food products. Exc Sci P Łódź Eng Chem Proc. 1999;24:29-46.

59. Iglesias H, Schebor C, Buera M, Chirife J. Sorption isotherms and calorimetric behavior of amorphous/crystalline raffinose-water system. J Food Sci. 2000;12:505-9.

60. Gondek E, Lewicki P. Moisture sorption isotherms of dried and candied fruits. Acta Sci Pol Technol Aliment. 2005;4(1):63-71.

61. Ciurzyńska A, Lenart A. Rehydration and sorption properties of osmotically pretreated freeze-dried strawberries. J Food Eng. 2010;97:267-74.

62. Spada J, Noreńa C, Marczak L, Tessaro I. Water adsorption isotherms of microcapsules with hydrolyzed pinhăo (Araucaria angustifolia seeds) starch as wall material. J Food Eng. 2013; 114:64-9. 